\title{
The management of snags: A comparison in managed and unmanaged ancient forests of the Southern French Alps
}

\author{
Damien MARAGE ${ }^{\mathrm{a}, \mathrm{b} *}$, Guy LEMPERIERE ${ }^{\mathrm{c}}$ \\ a LERFOB UMR INRA-ENGREF 1092, Unité Ecosystèmes Forestiers et Dynamique du Paysage, ENGREF, \\ 14 rue Girardet, 54042 Nancy Cedex, France \\ b Present address: UMR Biologie et Gestion des Adventices, INRA Dijon, Équipe Biodiversité, 17 rue Sully, 21000 Dijon, France \\ c Laboratoire d’Écologie Allpine, UMR-CNRS 5553, Université Joseph Fourier, BP 53, 38041 Grenoble Cedex 9, France
}

(Received 4 December 2003; accepted 29 September 2004)

\begin{abstract}
Dead wood is an important structure for conservation purposes and for maintaining biodiversity. In this context, snags were studied under different conditions in silver fir ancient forests of the southern French Alps. The impact of management status and developmental phases were estimated on both quantity and quality of this material. SDT volume averaged $64.6 \pm 19.8 \mathrm{~m}^{3} \cdot \mathrm{ha}^{-1}$ and $15.8 \pm 6.0 \mathrm{~m}^{3} \cdot \mathrm{ha}^{-1}$ in unmanaged and managed ancient forests, respectively. SDT volume varied according to the point in the silvicultural cycle and silvigenesis cycle ranging from $4.3 \pm 3.4 \mathrm{~m}^{3} \cdot \mathrm{ha}^{-1}$ in early aggradation phase of managed forests to $202.3 \pm 48.6 \mathrm{~m}^{3} \cdot \mathrm{ha}^{-1}$ in degradation phase of unmanaged forest. Large SDT significantly belonged to the degradation phase of unmanaged forests. Our research showed that SDT density in this ancient forests was mainly governed by natural processes. An average of 9 large SDT per ha has been proposed to preserve the ecological processes.
\end{abstract}

Alps / ancient forest / dead wood / ecological persistence / silver fir

Résumé - Gestion du bois mort sur pied : comparaison entre forêts anciennes gérées et subnaturelles des Alpes du Sud françaises. La quantité de bois mort est un enjeu important dans la conservation et le maintien de la biodiversité forestière. Dans ce contexte, les bois morts sur pied ont été étudiés dans des hêtraies-sapinières anciennes des Alpes du Sud françaises. L'impact du mode de gestion et des différentes phases du cycle sylvicultural et de la mosaïque sylvatique a été estimé. Le volume moyen de bois mort sur pied atteint $64,6 \pm 19,8 \mathrm{~m}^{3} \cdot \mathrm{ha}^{-1} \mathrm{dans}$ les forêts anciennes inexploitées, alors qu'il n'est que de $15,8 \pm 6,0 \mathrm{~m}^{3} \cdot \mathrm{ha}^{-1}$ dans les forêts exploitées. Ce volume moyen varie selon la mosaïque sylvatique, passant de $4,3 \pm 3,4 \mathrm{~m}^{3} \cdot \mathrm{ha}^{-1}$ dans la jeune phase d'aggradation des forêts anciennes exploitées à $202,3 \pm 48,6 \mathrm{~m}^{3} \cdot \mathrm{ha}^{-1} \mathrm{dans}_{\mathrm{a}}$ la phase de sénescence des forêts anciennes inexploitées. Cette dernière contient significativement les gros bois sec sur pied (DBH $>43 \mathrm{~cm}$ ). Nos résultats montrent que dans ces écosystèmes montagnards, la disponibilité en bois mort sur pied, est due essentiellement aux fortes contraintes environnementales en présence.

Alpes / bois mort / forêt ancienne / persistance écologique / sapin pectiné

\section{INTRODUCTION}

Over the last few decades, there has been an increasing recognition of snag resources as critical elements of forest ecosystems. Standing dead trees (SDT) or snags play a crucial role in the biodiversity and functioning of forest ecosystems [22, 39]. A wide range of plants and animals have been strongly associated with SDT. This is especially true with cavity-nesting birds which comprise $40 \%$ of the forest birds communities in France $[5,31]$ and also, saproxylic insects that achieve a part or their entire biological cycle in dead wood materials [13, 14, 42]. These functional groups take an active part in releasing nutrients in the biogeochemical cycles of forest ecosystems [7]. This decaying substrate is also associated with nitrogen-fixing bacteria that may contribute to soil nitrogen content [22]. Furthermore, the decaying wood can be an important seedbed for regenerating trees, ferns and mosses [11, 18, 22, 37].

Tree mortality is generally the result of complex interactions among multiple factors [18]. At various developmental phases, mortality processes differ. Biotic and abiotic disturbances were more important in the biostatic phase [25], since stem exclusions were rather rare in the innovation and aggradation phases [36]. These different mortality processes may interact with organisms dependent on SDT. Tree species, diameter and decay stages of SDT were factors that strongly regulated animal and plant species composition $[2,8,11,14]$. Forest management

\footnotetext{
* Corresponding author: damien.marage@ dijon.inra.fr
} 
Table I. Description of forest sites.

\begin{tabular}{|c|c|c|c|c|c|c|}
\hline Site & Area (ha) & Average elevation (m) & Main species & Management status & Silvicultural system & Date of last harvest \\
\hline Donnes & 119 & 1500 & Beech & Unmanaged & Biological reserve & 1892 \\
\hline Chapitre & 195 & 1450 & Silver fir & Unmanaged & Biological reserve & 1951 \\
\hline Ufernet & 82 & 1350 & Silver fir & Unmanaged & Biological reserve & 1954 \\
\hline Lescout & 104 & 1550 & Beech & Managed & Selection & 1984 \\
\hline L'Avalanche & 48 & 1500 & Silver fir & Managed & Selection & 1998 \\
\hline Tavanet & 85 & 1500 & Silver fir & Managed & Even-aged & 1998 \\
\hline
\end{tabular}

both by clear-cutting and selective thinnings could alter and modify the spatial and temporal availability of SDT [20, 24, 30].

From an economical point of view, snags were regarded as breeding material for insects, which might then attack living trees and depreciate timber values. Moreover, in managed forests, snags were also seen as a threat to public safety [37]. Starting a decade ago, the amount of dead wood, particularly SDT, has attracted attention of forest managers as a way to maintain biodiversity within forests managed for timber production [1]. Thus, maintenance of snags has become an integrated part of forest management in France [15]. There is limited information currently available concerning the amount and distribution of SDT in managed and unmanaged forests in France [13, 25, 40]. We assessed existing levels of snags in unmanaged ancient forests to provide a basis for what might be considered as high amounts of snags under present conditions. Undisturbed forest stands may be important for biodiversity through their content of microhabitats and for the long periods available for colonisation $[33,35]$. The aim of this work was to evaluate the amount of SDT in ancient silver fir-beech forests which was actively managed or unmanaged (reserve area). Because, qualitative (species) and quantitative (volume, size) parameters strongly regulated community organization, we described and compared SDT during the sylvicultural and sylvigenesis cycle. For this mountain ecosystem, our results should provide guidelines for forest managers to maintain and sustain biodiversity.

\section{MATERIALS AND METHODS}

\subsection{Study area}

The "Petit Buëch" watershed was an ideal site for the study of forest dynamics and related anthropic impacts because of its ecological homogeneity.

Therefore, the study was carried out in an experimental watershed, "Petit Buëch" located in the Hautes-Alpes (France) at $44^{\circ} 35^{\prime} \mathrm{N}$, $6^{\circ} 12$ ' E, ca. $10 \mathrm{~km}$ northwest of Gap. Covering a $57 \mathrm{~km}^{2}$ area, the watershed elevation varied between 960 to $2700 \mathrm{~m}$. The climate features stem from the AURELHY model of Météo France [4]; data from 1961 to 1990 . The mean annual rainfall was $1138 \mathrm{~mm}$ and the mean annual temperature values was $5.8^{\circ} \mathrm{C}$. Winters were cold with more than 100 days of frost and the snow cover usually lasting for ca. 150 days. The watershed lies essentially on a substratum from the Jurassic and Cretaceous periods.

Between 1300 and $1800 \mathrm{~m}$, a silver fir-beech forest has developed (Fagion sylvaticae; Trochiscantho nodiflori-Abietum albae) and is considered as a Potential Natural Vegetation [38]. The most influential dynamic factors in this forest, namely landslides, avalanches, diseases and death, windfalls, and outbreaks of insects lead to its structural heterogeneity, expressed in a silvatic mosaic [36], the complex of distinct patches of various developmental phases $[6,9,17,27]$.

\subsection{Sampling methods and design}

Six forests were selected to describe the amounts of SDT; three were harvested and three were unexploited for more than half a century (Tab. I). According to the land use history derived from the Napolean cadastral map (1808), we selected only ancient forests, defined as areas covered with forests since the 18th century or before [37].

Management status and developmental phases are two main factors that influence SDTs dynamics [20, 21, 28, 40]. Samples were taken exclusively in the neutrophilous silver fir-beech forest as site conditions also seemed to have an effect on SDTs [22, 44]. Infra Red Color cameras were used to distinguish between the four developmental phases and the data set was validated by field assessments. Dendrometrical features of each developmental phases were described in Table II. Both in managed and unmanaged forests, the early aggradation phase corresponded to a intensively self-thinning aggradation phase, the aggradation phase itself, corresponded to a pole stand, evenly structured, the biostatic phase represented generally by uneven mixed stand. Only represented in unmanaged forests, the degradation phase with gaps and regenerations, revealing an advanced break-down of old stand.

All maps were incorporated into a Geographic Information System (ArcInfo ${ }^{\mathrm{TM}}$ 8.1). Plots were located using a stratified random sampling procedure with management status (two levels, managed and unmanaged) and developmental phases (four levels), which defined the different strata. Seven experimental units per strata were selected, with seven plots per unit (Tab. II). A global positioning system (Trimble Geo Explorer) was used to establish the 49 field plots.

SDT of each species tree were recorded on circular $400 \mathrm{~m}^{2}$ plots. On each plot, all trees were measured if $\mathrm{DBH} \geq 7.5 \mathrm{~cm}$ (living or dead). The $7.5 \mathrm{~cm}$ threshold was chosen because it was the minimum diameter for trees recorded in the French National Forest Inventory. SDT were sampled only if they were at least $2 \mathrm{~m}$ tall. For each snag, height (m) was also recorded using a dendrometer (Bitterlich relascop). Trees were considered as SDT when the photosynthetic capacity was lost corresponding with 3, 4, 5 and 6 classes of Thomas [45].

\subsection{Data analysis}

For most analyses, SDTs were classified into four classes, 7.5 to $27.5 \mathrm{~cm} ; 28$ to $42.5 \mathrm{~cm} ; 43$ to $62.5 \mathrm{~cm}$; larger than $62.5 \mathrm{~cm} \mathrm{DBH}$. This is according to DBH classes in most stands studies in France. Large SDT was considered as above or equal to $43 \mathrm{~cm} \mathrm{DBH}$ and $4 \mathrm{~m}$ in height. 
Table II. Dendrometrical features of the developmental phases in ancient silver fir-beech forests of the southern French Alps. (Mean \pm SE; $n=14$, except for degradation phase, $n=7$.)

\begin{tabular}{lcccc}
\hline Developmental phases & Basal area $\left(\mathrm{m}^{2} \cdot \mathrm{ha}^{-1}\right)$ & Age (years) & Density $\left(\right.$ stem $\left.\cdot \mathrm{ha}^{-1}\right)$ & Height $(\mathrm{m})$ \\
\hline Early aggradation & $26.2 \pm 4.2$ & $36 \pm 5$ & $953 \pm 156$ & $10.0 \pm 0.9$ \\
Aggradation & $47.1 \pm 3.2$ & $48 \pm 3$ & $1494 \pm 102$ & $12.0 \pm 0.5$ \\
Biostatic & $42.2 \pm 2.5$ & $109 \pm 7$ & $748 \pm 85$ & $20.3 \pm 0.9$ \\
Degradation & $27.1 \pm 2.4$ & $141 \pm 21$ & $558 \pm 57$ & $20.8 \pm 1.8$ \\
\hline
\end{tabular}

Table III. Mean ( \pm SE) volume $\left(\mathrm{m}^{3}\right)$ and density (stems) per hectare of Standing Dead Trees (SDT) grouped by management status and developmental phase in ancient silver fir-beech forests of the southern French Alps.

\begin{tabular}{lccccc}
\hline & \multicolumn{2}{c}{ Volume $\left(\mathrm{m}^{3}\right)$} & & \multicolumn{2}{c}{ Density $\left(\mathrm{stem} \cdot \mathrm{ha}^{-1}\right)$} \\
\cline { 2 - 3 } \cline { 5 - 6 } \cline { 5 - 6 } & Managed & Unmanaged & & Managed & Unmanaged \\
\hline Early aggradation & $4.3 \pm 3.4$ & $12.9 \pm 6.2$ & & $14.3 \pm 9.2$ & $39.3 \pm 14.3$ \\
Aggradation & $9.8 \pm 3.9$ & $7.5 \pm 6.1$ & & $50.0 \pm 14.4$ & $17.8 \pm 7.1$ \\
Biostatic & $33.3 \pm 16.3$ & $35.6 \pm 17.3$ & & $23.2 \pm 10.4$ & $32.2 \pm 18.6$ \\
Degradation & - & $202.3 \pm 48.6$ & & - & $100.0 \pm 38.9$ \\
\hline
\end{tabular}

Derived from the measurement with the Bitterlich relascop, the volume was estimated using the commercial formula as below:

$$
v=\frac{\pi}{4} D^{2} H t \quad\left(\mathrm{~m}^{3}\right)
$$

with $H t=$ height of the snag and $D=$ diameter at middle-height.

SDT's basal area $(\mathrm{g})\left(\mathrm{m}^{2} \cdot \mathrm{ha}^{-1}\right)$ was calculated and a necrotic index was computed as follows:

$$
100\left[g_{\mathrm{SDT}} / g_{\text {tot }}\right]
$$

with $g_{\text {tot }}=g$ of living and dead tree.

This index allows one to describe the evolution of the basal area though managed versus unmanaged forests. SDT components were described using standard estimators of density (stems.ha-1) and volume $\left(\mathrm{m}^{3} \cdot \mathrm{ha}^{-1}\right)$. We used a chi-square test to perform a classical test of the null hypothesis that SDT density per species are independent. For these estimators and the necrotic index, a square-root transformation was used to stabilize variance $[12,29]$. Analysis of variance was used to assess the effects of management status and developmental phases. All ANOVAs were followed by a multiple comparison procedure (Least Significant Difference, LSD) to differentiate among treatment mean with a significant level of $P=0.05$.

\section{RESULTS}

\subsection{Quantity of SDT in managed and unmanaged ancient forests}

The overall mean $( \pm$ SE) of SDT density was $39.5 \pm$ $7.7 \mathrm{stem} \cdot \mathrm{ha}^{-1}$ which represents a volume of $43.7 \pm 12.0 \mathrm{~m}^{3} \cdot \mathrm{ha}^{-1}$ on average. Managed forest had $29.2 \pm 7.2 \mathrm{stem} \cdot \mathrm{ha}^{-1}$ compared with $47.3 \pm 12.4 \mathrm{stem} \cdot \mathrm{ha}^{-1}$ in unmanaged ones. SDT volume had an average of $64.6 \pm 19.8 \mathrm{~m}^{3} \cdot \mathrm{ha}^{-1}$ in unmanaged forests as compared to $15.8 \pm 6.0 \mathrm{~m}^{3} \cdot \mathrm{ha}^{-1}$ in managed forests.

The volume of SDT $\left(\mathrm{m}^{3} \cdot \mathrm{ha}^{-1}\right)$ was not evenly distributed among management status and developmental phases (Tab. III). It varied considerably both over the silvicultural and silvigenesis cycles ranging from $4.3 \pm 3.4 \mathrm{~m}^{3} \cdot \mathrm{ha}^{-1}$ in the early aggradation phases of managed forests to $202.3 \pm 48.6 \mathrm{~m}^{3} \cdot \mathrm{ha}^{-1}$ in the degradation phase of unmanaged ones. The difference was significant among management status and developmental phases (Tab. IVa). The degradation phase had a significantly greater volume of SDT than all other developmental phases $(P<0.05$; LSD). The results for the volumes were not significantly different when the degradation phase was not included in the analysis.

Density of SDT was not be affected by management status but was affected by developmental phase (Tab. IVb). The degradation phase appeared to have a significantly greater density of SDT than all other developmental phases except for the aggradation phase of the managed forests (Tab. III).

Within managed forests, both volume and density of SDT did not differ significantly between developmental phases.

Table IV. Summary of two way ANOVA on the effects of management status and developmental phases on SDTs volume (a) and SDTs density (b).

\begin{tabular}{lccccccc}
\hline Response: SDT volume & (a) & & & Response: SDT density & (b) \\
\hline Source of variation & $d f$ & $F$ & $P$ & Source of variation & $d f$ & $F$ & $P$ \\
Management status & 1 & 7.89 & 0.007 & Management status & 1 & 1.34 & 0.25 \\
Developmental phases & 3 & 17.39 & 0.000 & Developmental phases & 3 & 3.52 & 0.02 \\
\hline
\end{tabular}




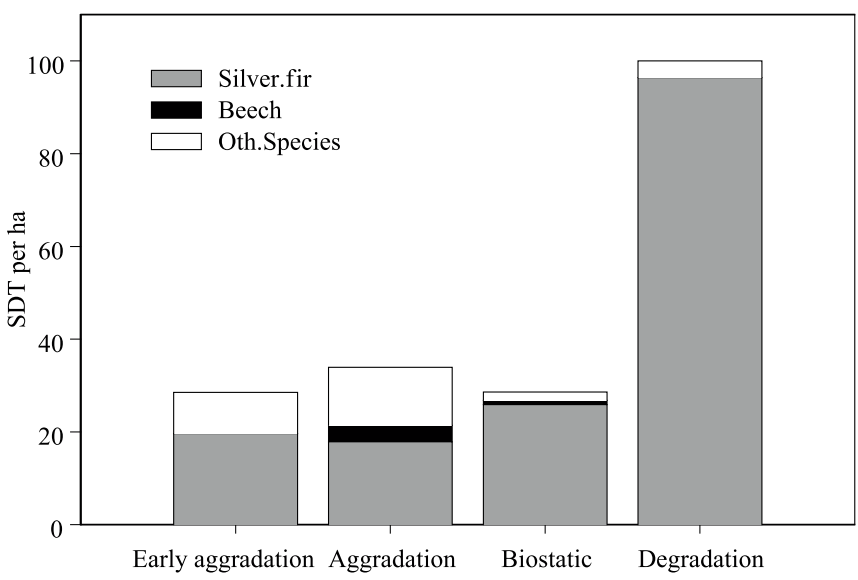

Figure 1. Relationship between mean density per hectare of Standing Dead Trees (SDT) and developmental phase stacked by species in ancient silver fir-beech forest of the southern French Alps.

\subsection{Size class distribution}

\subsubsection{Snag species distribution}

All plots considered, SDT was essentially composed of silver fir, which represented $96 \%$ of the volume and $75 \%$ of the stems. Beech SDT was less important representing $1 \%$ of the volume and $5 \%$ of the stems. Other broadleaves represented $20 \%$ of the SDT stems, especially in the early aggradation and the aggradation phases of the unmanaged forest.

Silver fir was the dominant species of snags ranging from $68 \%$ of the stems in the early aggradation phase to $96 \%$ in the degradation one. However, proportions of different SDT species varied among developmental phases in terms of density $\left(\chi^{2}=\right.$ 500.31, $d f=6, P<0.0001)$. As expected, a higher proportion of other broadleave tree species (Fraxinus excelsior L., Acer pseudoplatanus L., Laburnum alpinum (Mill.) Bercht. \& J. Prest) were found in early aggradation and aggradation phases, respectively representing $31 \%$ and $37 \%$ of the density. Beech snags were absent in the early aggradation phase as expected given its shade resistance (Fig. 1).

The proportion of different SDT species varied among management status in terms of density $\left(\chi^{2}=56.68, d f=2\right.$, $P<0.0001)$. Broadleave tree varied from $11 \%$ of the stems in managed forests to $23 \%$ of the stems in the unmanaged forests.

\subsubsection{Snag diameter distribution}

In managed forests, the mean snag density (stems $\cdot \mathrm{ha}^{-1}$ ) decreased from $20.8 \pm 6.3$ for the first DBH class to $3.6 \pm 1.9$ for 43-62.5 DBH class, indicating a typical reverse J size distribution (Fig. 2). There were no large snags in the last DBH class indicating large snags are rarely formed.

In unmanaged forests, the same pattern of distribution was observed, except that there were snags in the last DBH class $\left(10.7 \pm 3.3 \mathrm{stem} \cdot \mathrm{ha}^{-1}\right)$. Large snags typically were found in the

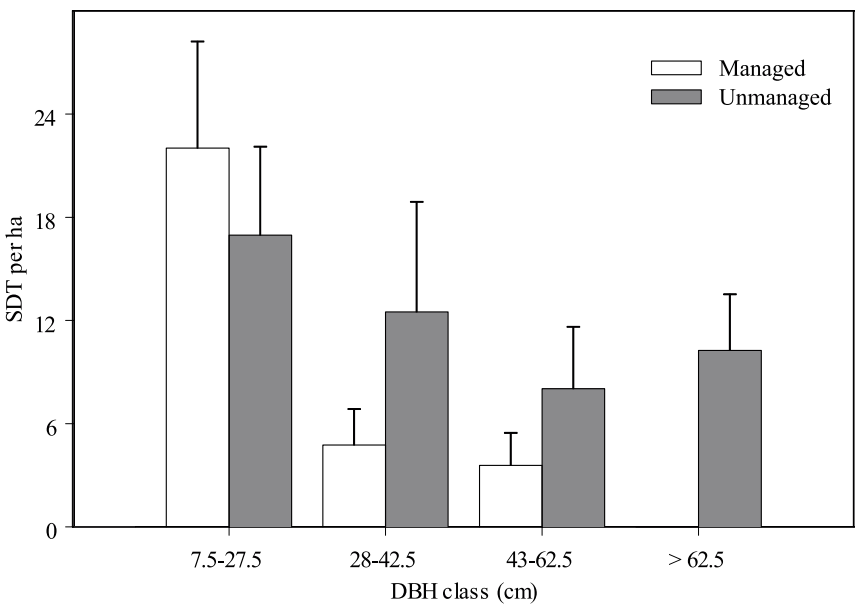

Figure 2. Mean density per hectare of Standing Dead Trees (SDT) grouped by management status in ancient silver fir-beech forests of the southern French Alps (error bars represent $1 \mathrm{SE}$ ).

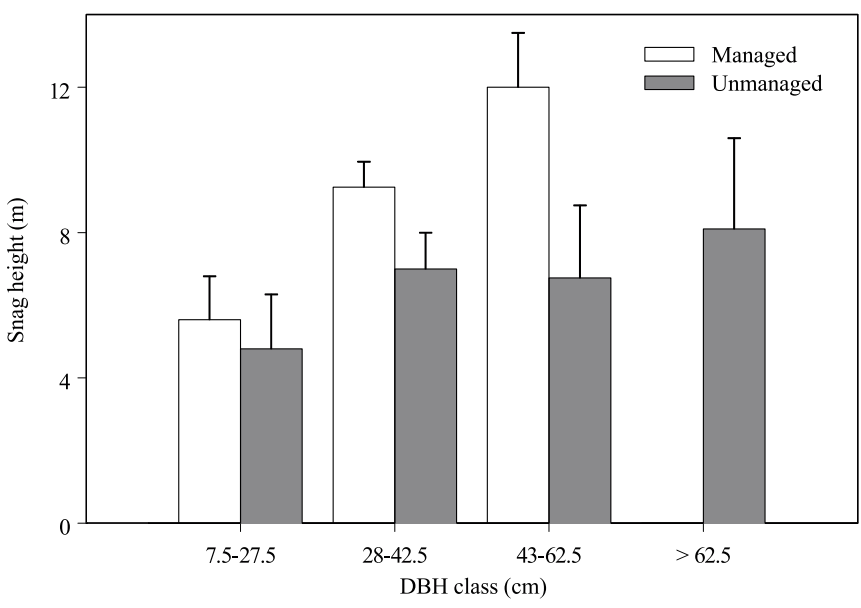

Figure 3. Mean height (m) of Silver fir Standing Dead Trees (SDT) grouped by management status in ancient silver fir-beech forests of the southern French Alps (error bars represent $1 \mathrm{SE}$ ).

degradation phase. An average density of 3.6 large SDT $\cdot$ ha $^{-1}$ was found in managed forests in contrast to an average density of 19 large SDT $\cdot$ ha $^{-1}$ in unmanaged forests.

\subsubsection{Snag height distribution}

No trend was detected in snag height distribution of beech and other broadleaves with average height of $3.6 \pm 0.6 \mathrm{~m}$ and $4.6 \pm 0.6 \mathrm{~m}$, respectively. In contrast, mean silver fir SDT height (Fig. 3) varied across DBH class both in managed and unmanaged sites with significantly greater height in managed forest ( $t=3.69, P=0.0002$ ). However, mean silver fir snag height was fairly even among DBH class in unmanaged forests, but significant differences appeared in the managed ones $(d f=$ $3, F=6.75, P=0.0001)$. In the $43-62.5 \mathrm{DBH}$ class, silver fir 


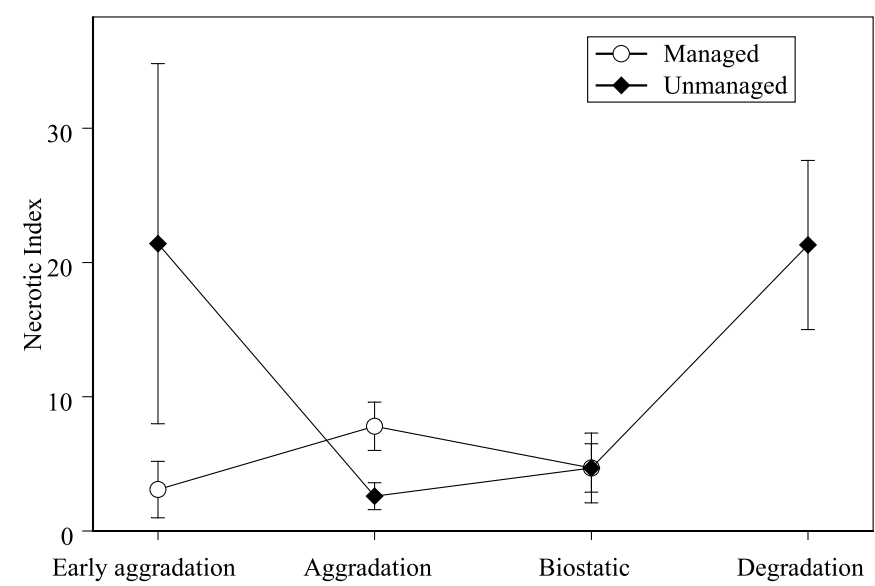

Figure 4. Mean values of the necrotic index among Management status and developmental phases in ancient silver fir-beech forests of the southern French Alps (error bars represent $1 \mathrm{SE}$ ).

snag height reached $13.0 \pm 1.4 \mathrm{~m}$ on average, approximately half the height of live trees of the same DBH class (Mortier, unpublished data; Marage, unpublished data). In unmanaged sites, the height of snags was higher in the last DBH class. This situation was due to the broad range of stages of decomposition of this DBH class.

\subsection{Dynamics of SDT across the developmental phases}

We observed no significant effects of management on the necrotix index $(d f=1, F=2.5, P=0.12)$ but a significant one across developmental phases $(d f=3, F=2.89, P=0.04)$. In managed forests, the necrotic index varied from $3.0 \pm 2.0$ in the early aggradation phase up to $7.8 \pm 1.8$ in the aggradation phase, and $4.7 \pm 1.8$ in the biostatic phase (Fig. 4).

This "humped-back" shape was partly due to silvicultural practices and also to stem exclusion in the aggradation phase that produced large numbers of small snags, resulting from a high tree mortality. Diseased and decaying trees were felled and removed from the stand. In unmanaged stands, a U shaped distribution was observed, with similar values in the early aggradation phase $(21.4 \pm 13.4)$ and the degradation phase $(21.3 \pm 6.3)$.

\section{DISCUSSION}

\subsection{Amounts of SDT in managed and unmanaged ancient forests}

Snags appeared to be relatively abundant in our study area. Many authors observed that a large reduction of SDT was typical of managed forests [2, 20, 21, 24]. Those studies had not also considered the sylvatic cycle in general and contained no replications in experimental design. Our results showed no significant difference in density and volume unless the amount of
SDT belonging to the degradation phase was taken into account. This last point supported the significance of the degradation phase in the overall structure of the forest ecosystem $[17,27,37]$. These results can be explained if land use history and disturbance regimes are taken into account. Indeed, this mountain ecosystem was subject to drastic environmental constraints like landslides, avalanches and drought stress. Moreover, the "Petit Buëch" watershed is on the biogeographical boundary of silver fir extent. This context is favourable to mistletoe (Viscum album L.) and Melampsorella caryophyllacearum infestations. Because the environmental constraints were almost similar between sites, these natural disturbances erased the effects of harvesting.

SDT varied across developmental phases as recorded by McCarthy and Bailey (1994) [30], Guby and Dobbertin (1996) [21], Green and Peterken (1997) [20], Strurtevant et al. (1997) [44], Schnitzler and Borléa (1998) [40] and Lee (1998) [26]. Despite not distinguishing the stage of decomposition, silver fir snag height was higher in managed forests due to an early stage of decomposition. Snag height was strongly negatively correlated with advanced decay classes [18, 19]. In unmanaged stands, snag height was relatively constant, with no significant difference among DBH classes. Mortality rates and probability of fallen wood increased with time. For example, in a sub-alpline coniferous stand, up to 20 years elapsed before snags started to fragment and half the volume might still be standing 80 years after the trees have died [37]. If snag height was constant among DBH class and/or developmental phase, there was time enough for the catabolic processes to occur. If snag height was adjusted with living tree height, silvicultural operations could interfere with catabolic processes.

In unmanaged forests, the high variance in the necrotic index in the early aggradation phase indicated that SDT remained from the degradation phase. In the early aggradation, competitive exclusion was considerable among the young stems, contributing to the development of a pool of small dead trees. The remaining trees formed the pool of old trees dying from the degradation phase. In the degradation phase, large stems formed; the pool of dead trees, in some plots, the number of dead trees was higher than the living trees (necrotic index higher than 100), demonstrating that catabolic processes were more important than the anabolic processes in that case. Futhermore, death processes appeared in clumps because the agents of disease like insects, landslides and drought stress act in a localized area.

Because of different lower sizes, an exact quantitative comparison in volume with others studies is difficult. Unfortunately, no published data were available in French silver fir-beech forests. But, in eastern Europe, Leibundgut [27] described untouched silver fir beech forest in Slovakia and reported a mean SDT volume of $348 \mathrm{~m}^{3} \cdot \mathrm{ha}^{-1}$ in the degradation phase and $171 \mathrm{~m}^{3} \cdot \mathrm{ha}^{-1}$ in the biostatic phase. These results were similar to our maximum values. Mean volume of silver fir snags belonging to the biostatic phase had a similar value $\left(2.5 \mathrm{~m}^{3}\right.$ per tree) than those found in primeval forests in Slovakia. In a pure silver fir virgin forest in Switzerland, Leibundgut [27] noted 60 to $171 \mathrm{~m}^{3} \cdot \mathrm{ha}^{-1}$ of SDT, which was also comparable with the values found in our unmanaged sites. Our results on density were higher than those reported by Leibundgut. 
Results from other forest types in Europe gave comparable values. In Switzerland, Guby and Dobbertin [21] reported an average of $9.3 \mathrm{~m}^{3} \cdot \mathrm{ha}^{-1}$ in unmanaged sites and $1.1 \mathrm{~m}^{3} \cdot \mathrm{ha}^{-1}$ in the managed ones; a same trend was observed in the percentage of SDT above $35 \mathrm{~cm}$ with respectively $61 \%$ in the unmanaged sites and $7 \%$ in the managed ones as compared to $57 \%$ and $23 \%$ in our study. Kirby et al. [24] observed the same lack of SDT above $40 \mathrm{~cm} \mathrm{DBH}$ in the managed sites of some selected forests in England as we noticed in our study site. In most of the mixed forests of Europe, the SDT density of unmanaged old-growth forests varied from 2.7 to $41.8 \mathrm{stem} \cdot \mathrm{ha}^{-1}$ in England [20] to 1 to $20 \mathrm{stem} \cdot \mathrm{ha}^{-1}$ in France $[25,40]$. In Swedish boreal landscapes, a density of almost $35 \mathrm{SDT} \cdot \mathrm{ha}^{-1}$ which represented a volume of $13 \mathrm{~m}^{3} \cdot \mathrm{ha}^{-1}$ in old growth spruce forests was reported [23].

Results from other ecosystems in North America gave values similar to those found in our study. In broadleaf forests, ranging from boreal to temperate climate, SDT density increased [19, 26, 30, 44]. In temperate rain forests dominated by Douglas-fir, a significantly higher density was observed [22, 43]. The results for the SDT in the present study were similar to the results found by Strurtevant et al. [44] in mixed Balsam fir forest of Newfoundland (USA).

\subsection{Forestry implications}

One of the underlying goals of our study was to provide initial baseline data regarding forest management. The management of SDT resources should consider the spatial arrangement and dynamics of all components of habitats for each species or functional group to provide a continuum of snag habitat accross the landscape.

In France, a mean volume of SDT of $1.63 \mathrm{~m}^{3} \cdot \mathrm{ha}^{-1}$ was estimated in 1999 [3]. Our study showed that the effect of harvesting was underestimated in this mountain ecosystem and gave results higher than the national average and the empirical recommendations provided by forest managers [15]. These results could encourage forest managers to preserve the other broadleave trees from the early aggradation phase to increase their abundance in the SDT pool. Those species should not be eliminated to respect the original mixtures of broadleave trees [32] even if they are products of little or no commercial value. Such management measures might provide breeding and foraging habitats for both vertebrates and invertebrates.

Several authors described natural forests as an important area of necromass accumulation [17, 27, 37, 41]. Based on our result, we suggest that the amount of dead wood is not sufficient to characterize the naturalness of a forest ecosystem. Only large SDT showed a difference between silvicultural and silvigenesis cycles. Forest management harvests trees at diameter always lower than the maximum biological diameter [16]. Therefore, large snags were scarce because trees were harvested before they reach large diameters. Achieving naturalness would then mean getting closer to natural silvigenetic models. This notion could be formalized in ecological terms by means of two parameters. Large snags belonging to commercial species and a biomass flow per year and per hectare measuring the intensity of anthropogenic disturbance. In our case, we observed an average density of 9 large SDT.ha ${ }^{-1}$ in unmanaged forests, com- pared with 3.6 large SDT'ha ${ }^{-1}$ in managed forests. Bull et al. [8] recommended a minimum of $10 \mathrm{stem} \cdot \mathrm{ha}^{-1}$ higher than $50 \mathrm{~cm} \mathrm{DBH}$ to encompass the diversity of wildlife, especially for cavity nester populations. These values were adequate with those observed in the unmanaged ancient forests of our study site. In the same time, Ganey (1997) [19] did not observed this values of SDT when working on unmanaged Pinus ponderosa stands of Arizona. The decision making of which trees to maintain during management activities have been driven by tree species, tree volume and cost associated with forgoing timber value and the range of forest productivity [34].

\subsection{Landscapes, biodiversity implications and perspectives}

Both spatial and temporal patterns of availability must be taken into account to provide a continuum of snag habitats in landscapes. Jonsson [23] indicated that Coarse Woody Debris (CWD) could be very common both in space and time in natural forests. It is likely that species with fairly low dispersal ability and/or very special substrate demands have developed. Presently, these species might have serious problems with increasing temporal and spatial gaps in the availability of CWD density within managed stands and an increasing distance between remnant old growth stands. In our study sites, the spatial pattern of forests and especially the neighbourhood of unmanaged and managed forests could maintain all the components of biodiversity.

The death of trees in a forest could be caused by several abiotic factors (pollution, drought stress, unsuitable sites) and/or biotic factors (presence of pathogens, defoliations, attacks by bark beetles) under biocenotic sequences $[10,13]$. The presence of different forms of dead wood in a forest could be considered as the result of the decay of a certain percentage of trees or parts of trees and measured in numbers of individuals per hectare or in volume per hectare as previously mentioned in our study. This dead wood then vary in quality or forms and quantity according to the management status of the forest and has been characterized by a long series of processes as described by Mc Comb and Lindenmayer [31], Dajoz [14] and Thomas [45]. As mentioned by Kirby (1993), "a wide range of dead wood should be retained in any woodland managed for conservation". The value of SDT and CWD for conservation purposes could be of great importance as a large number of invertebrates are associated with this material. The value of SDT and dead wood in general is high for conservation purposes and for maintaining the biodiversity. Accordingly a minimum volume of SDT per hectare is required for habitat and species conservation and still has to be estimated in a case by case basis. This volume has to be compatible with the overall management of the forest. More information is necessary on fallen dead wood and CWD, and more precisely on the temporal availability and decay rates. Our question and concern about managed forests and necromass are focussed on the compatibility of the presence of dead wood material and silvicultural operations. A local and temporary forest pest problem could then be considered as a potential and optional candidate for maintaining the habitat diversity of SDT and CWD. An integrated forest management could then 
be a compromise between forest pest management and conservation management. Thus, a real policy of protected area conservation will be needed, in France and Europe, to maintain or restore ecological processes at a large scale.

Acknowledgements: We would like to thank the "Office National des Forêts" (France) for granting permission to sample in their forests. We also thank three anonymous reviewers for valuable comments on early drafts of this manuscript. This research was funded by GIP ECOFOR grant No. 99.02.

\section{REFERENCES}

[1] Ammer U., Implications of the results of research on dead wood for forestry practice, Forstwiss. Centralbl. 110 (1991) 149-157.

[2] Andersson L.I., Hytteborn H., Bryophytes and decaying wood: a comparison between managed and natural forest, Holarc. Ecol. 14 (1991) 121-130.

[3] Barthod C., Les Indicateurs de gestion durable des forêts françaises, Ministère de l'Agriculture et de la Pêche, Paris, 2000.

[4] Benichou P., Le Breton O., Prise en compte de la topographie pour la cartographie des champs pluviométriques statistiques, Météorologie 19 (1987) 25-42.

[5] Blondel J., Biogéographie. Approche écologique et évolutive, Masson, Paris, 1995.

[6] Bobiec A., Living stands and dead wood in the Bialowieza forest: suggestions for restoration management, For. Ecol. Manage. 165 (2002) 125-140.

[7] Bormann F.H., Likens G.E., Pattern and Process in a Forested Ecosystem, Springer-Verlag, New-York, 1994.

[8] Bull E.L., Parks C.G., Torgersen T.R., Trees and logs important to wildlife in the interior Columbia river basin, Portland: USDA Forest Service Pacific NW Region, 1997.

[9] Christensen M., Emborg J., Biodiversity in natural versus managed forest in Denmark. Conservation of biological diversity in temperate and boreal forest ecosystems, For. Ecol. Manage. 85 (1996) 47-51.

[10] Coudroy J.P., Enchaînement biocénotique des insectes xylophages du Sapin (Abies alba L.) en vallée d'Ossau: description des deux premiers groupes d'espèces, Documents d'écologie pyrénéenne IIIIV (1984) 97-100.

[11] Crites S., Dale M.R.T., Diversity and abundance of bryophytes, lichens and fungi in relation to woody substrate and successional stage in aspen mixedwood boreal forests, Can. J. Bot. 76 (1997) 641-651.

[12] Dagnelie P., Théorie et méthodes statistiques. Applications agronomiques, Presses agronomiques de Gembloux, Gembloux, 1975.

[13] Dajoz R., Les insectes xylophages et leur rôle dans la dégradation du bois mort, in: Pesson P. (Ed.), Écologie forestière, GauthierVillars, Paris, 1974, pp. 257-287.

[14] Dajoz R., Écologie des insectes forestiers, Gauthier-Villars, Paris, 1998.

[15] Direction technique de l'Office National des Forêts, Prise en compte de la diversité biologique dans l'aménagement et la gestion forestière, Office National des Forêts, Fontainebleau, 1993.
[16] Dubourdieu J., Manuel d'aménagement forestier, Tec \& Doc, Lavoisier, Paris, 1997.

[17] Falinski J.B., Vegetation dynamics in temperate lowland primeval forests, Ecological studies in Bialowieza Forest, Junks, Dordrecht, 1986.

[18] Franklin J.F., Shugart H.H., Harmon M.E., Tree death as an ecological process, BioScience 37 (1987) 550-556.

[19] Ganey J.L., Snag density and composition of snag populations on two National Forests in northern Arizona, For. Ecol. Manage. 117 (1999) 169-178.

[20] Green P., Peterken G.F., Variation in the amount of dead wood in the woodlands of the Lower Wye Valley UK, in the relation to the intensity of management, For. Ecol. Manage. 98 (1997) 229-238.

[21] Guby N.A.B., Dobbertin M., Quantitative estimates of coarse woody debris and standing dead trees in selected Swiss forests, Glob. Ecol. Biogeogr. Lett. 5 (1996) 327-341.

[22] Harmon M.E. et al., Ecology of coarse woody debris in temperate ecosystems, Adv. Ecol. Res. 15 (1986) 133-302.

[23] Jonsson B.G., Availability of coarse woody debris in a boreal oldgrowth Picea abies forest, J. Veg. Sci. 11 (2000) 51-56.

[24] Kirby K.J., Webster S.D., Anctzak A., Effects of forest management on stand structure and quantity of fallen dead wood: some British and Polish examples, For. Ecol. Manage. 43 (1991) 167-174.

[25] Koop H., Hilgen P., Forest dynamics and regeneration mosaic shifts in unexploited beech (Fagus sylvatica) stands at Fontainebleau (France), For. Ecol. Manage. 20 (1987) 135-150.

[26] Lee P., Dynamics of snags in aspen-dominated midboreal forests, For. Ecol. Manage. 105 (1998) 263-272.

[27] Leibundgut H., Europäische Urwälder, Paul Haupt, Berne, 1993.

[28] Lemée G., Structure et dynamique de la hêtraie des réserves biologiques de la forêt de Fontainebleau : un cas de complexe climacique de forêt feuillue monospécifique tempérée, Acta. Oecol. Oecol. Gen. 10 (1989) 155-174.

[29] MathSoft, S-Plus 2000, Guide to Statistics, MathSoft, Inc., Washington, 1999.

[30] Mc Carthy B.C., Bailey R.R., Distribution and abundance of coarse woody debris in a managed forest landscape of the central Appalachians, Can. J. For. Res. 24 (1994) 1317-1329.

[31] McComb W., Lindenmayer D., Dying, dead, and down trees, in Hunter M.L. (Ed.), Maintaining biodiversity in forest ecosystems, Cambridge University Press, Cambridge, 1999, pp. 335-361.

[32] Motta R., Garbarino F., Stand history and its consequences for the present and future dynamic in two silver fir (Abies alba Mill.) stands in the high Pesio Valley (Piedmont, Italy), Ann. For. Sci. 60 (2003) 361-370.

[33] Nagaike T., Hayashi A., Effects of extending rotation period on plant species diversity in Larix kaempferi plantations in central Japan, Ann. For. Sci. 61 (2004) 197-202.

[34] Nilsson S.G., Niklasson M., Hedin J., Aronsson G., Gutowski J.M., Linder P., Ljungberg H., Mikusinski G., Ranius T., Densities of large living and dead trees in old-growth temperate and boreal forests, For. Ecol. Manage. 161 (2002) 189-204.

[35] Norden B., Appelqvist T., Conceptual problems of Ecological Continuity and its bioindicators, Biodiv. Conserv. 10 (2001) 779-791.

[36] Oldeman R.A.A., Forest, Elements of sylvology, Springer-Verlag, Berlin, 1990.

[37] Peterken G.F., Natural woodland, Ecology and conservation in Northen temperate regions, Cambridge University Press, Cambridge, 1996. 
[38] Rameau J.C., Dynamique de la végétation à l'étage montagnard dans les Alpes du sud. Première approche des hêtraie-sapinières. Les applications possibles au niveau de la gestion, Rev. For. Fr. 44 (1992) 393-413.

[39] Samuelsson J., Gustafsson L., Ingelög T., Dying and dead trees : a review of their importance for biodiversity, Swedish Threatened Species Unit, Uppsala, 1994.

[40] Schnitzler A., Borlea F., Lessons from natural forests as keys for sustainable management and improvement of naturalness in managed broadleaved forests, For. Ecol. Manage. 109 (1998) 293-303.

[41] Speight M., Saproxylic invertebrates and their conservation, Council of Europe, Strasbourg, 1989.
[42] Speight M.R., Wainhouse D., Ecology and management of forest insects, Clarendon press, Oxford, 1989.

[43] Spies T.A., Franklin J.F., Thomas T.D., Coarse woody debris in Douglas-fir forests of western Oregon and Washington, Ecology 69 (1988) 1689-1702.

[44] Strurtevant B.R., Bissonette J.A., Long J.N., Roberts D.W., Coarse woody debris as a function of age, stand, structure and disturbance in boreal Newfoundland, Ecol. Appl. 7 (1997) 702-712.

[45] Thomas J.W., Wildlife habitats in managed forests in the Blue mountains of Oregon and Washington, Portland, USDA Forest Service Pacific NW Region, 1979. 